\title{
Inhibitory Effects of Sangketan (Achyranthes aspera L.) Roots Extract on Arginase Activity and Determination of Its Total Phenolic and Flavonoid Contents
}

\author{
Dieah Siti Rahmawati, Berna Elya*, Arikadia Noviani
}

\section{Dieah Siti Rahmawati, Berna} Elya*, Arikadia Noviani

Department of Pharmacognosy and Phytochemistry, Faculty of Pharmacy, University of Indonesia, Depok 16424 West, INDONESIA.

\section{Correspondence}

Berna Elya

Department of Pharmacognosy and Phytochemistry, Faculty of Pharmacy, University of Indonesia, Depok 16424 West, INDONESIA.

Phone no: +6281314161497

E-mail: berna.elya@farmasi.ui.ac.id

History

- Submission Date: 10-12-2018;

- Review completed: 12-04-2019;

- Accepted Date: 24-05-2019.

DOI : 10.5530/pj.2019.11.191

Article Available online

http://www.phcogj.com/v11/i6

\section{Copyright}

(C) 2019 Phcogj.Com. This is an openaccess article distributed under the terms of the Creative Commons Attribution 4.0 International license.

\begin{abstract} arginase inhibitory activity. Total phenolic content.

\section{INTRODUCTION}

Sangketan or Achyranthes aspera L. is a plant that is often used in Indonesia. Traditionally, the roots of Sangketan are used as wound healers. Several studies also mentioned that Sangketan can act as diuretic agent, antiobesity, antibacterial, antioxidant, wound healer and immunomodulatory. ${ }^{1}$ It contained several chemical compounds like alkaloid, saponin, amino acid, steroid, triterpenoid, also phenolic compound and flavonoid. ${ }^{2}$
\end{abstract}

Background: Achyranthes aspera, or commonly called as Sangketan in Indonesian is a wild plant that is used as a traditional medicine. The roots of Sangketan can be used as a wound healer by involving the role of arginine and its metabolites, nitric oxide, that directly affect the wound healing process itself. Objective: The aim of this study is to determine the potential of Sangketan roots extract in inhibiting arginase activity. Methods: The roots were extracted using multistage ultrasound-assisted extraction method with n-hexane, ethyl acetate and methanol solvent. Each extract from different solvents was tested for the inhibition of arginase activity using a microplate-based colorimetric method, followed by determination of total phenolic concentration and total flavonoid concentration. Results: The results of inhibition test of arginase activity by $n$-hexane, ethyl acetate and methanolic extracts were 9.56; 17.58; and $29.77 \%$ sequentially/respectively at concentration of $100 \mu \mathrm{g} / \mathrm{ml}$; the total phenolic concentration were $3.91 ; 4.83$; dan $11.18 \mathrm{mgGAE} / \mathrm{g}$ of sample respectively; and the total flavonoid concentration are $0.29 ; 0.80$; and $0.88 \mathrm{mgQE} / \mathrm{g}$ of sample respectively. Conclusion: From this research, it can be concluded that Sangketan roots extract had low potency of

Key words: Achyranthes aspera, Arginase, Inhibitory effect, Sangketan, Total flavonoid content,

Optimal wound healing can be achieved by paying more attention to factors that can affect the continuity of the process. Arginine is one of the important factors because its metabolite-nitric oxide-is needed during the healing process. Nitric oxide is produced by endothelial nitric oxide synthase (eNOS) with L-arginine as substrate on endothelial cells. When the wound occurs, the amount of arginine can decrease dramatically, affecting the amount of $\mathrm{NO}$ and the healing process of the wound itself. ${ }^{3}$

Besides being influenced by arginine, the amount of NO can also be affected by the presence of the arginase which will hydrolyze arginine to form ornithine and urea in the urea cycle. However, due to a lot of arginase expressions in cells that are related to the wound healing process, arginase will compete with eNOS to use arginine in the urea cycle. ${ }^{4}$ That is why the use of arginase inhibitors can increase the amount of arginine availability in the wound environment. ${ }^{5}$ Several studies have found that inhibition activity of arginase enzymes is presence in plant extracts that contain polyphenols such as flavonoids and resveratrol. ${ }^{6}$ Research conducted by Bordage et al. ${ }^{6}$ showed the existence of inhibition activity of arginase from several plant compounds such as resveratrol, quercetin, chlorogenic acid and epicatecin. According to Cray et al. ${ }^{7}$ polyphenol compounds can act as chaotropic agents-compounds that can disrupt hydrogen bonds between water molecules. These previous researches' results showed that further research to find other effective compounds in inhibiting arginase is needed, especially using plants which can potentially be a source of new active agents. ${ }^{8}$

\section{MATERIALS AND METHODS}

\section{Materials}

The roots of Sangketan was obtained from Klaten, Central Java, Indonesia. The chemicals and reagents were sources commercially. Arginase, L-arginine, maleic acid and $\mathrm{MnSO}_{4}$ from Sigma Aldrich (Singapore); quercetin and gallic acid from Sigma Aldrich (India); resveratrol from Wako (Japan); urea kit assay from Abnova (Taiwan); n-hexane, ethyl acetate and methanol from Merck (Germany).

\section{Preparation of Sangketan roots extract}

\section{Extraction}

Dried Sangketan roots were grinded into powder (500 g) which then was extracted using multistage

Cite this article: Rahmawati DS, Elya B, Noviani A. Inhibitory Effects of Sangketan (Achyranthes aspera L.) Roots Extract on Arginase Activity and Determination of Its Total Phenolic and Flavonoid Contents. Pharmacog J. 2019;11(6):1231-4. 
ultrasound-assisted extraction and evaporated. n-hexane, ethyl acetate and methanol in sequence were used as the solvent of multistage extraction.

\section{Arginase activity inhibition test}

The inhibition test was modified from the protocols published by Sigma Aldrich (EC 3.5.3.2). The sample solution was made by mixing $10 \mu \mathrm{L}$ extract, $15 \mu \mathrm{L}$ arginase $1 \mathrm{U} / \mathrm{mL}$ and $20 \mu \mathrm{L}$ L-arginine substrate 380 $\mathrm{mM}$. Then the sample solution was preincubated at $37^{\circ} \mathrm{C}$ for $30 \mathrm{~min}$. Right after the preincubation, $100 \mu \mathrm{L}$ urea assay reagent was added and then incubated at room temperature for an $h$. The inhibition activity of arginase was determined on microplate reader (Epoch, USA). ${ }^{9}$ Resveratrol was used as positive control of arginase inhibition because resveratrol easily found on plant and it could be on higher rank in terms of inhibitory effect $\left(\mathrm{IC}_{50}\right)$ amongst other compounds such as epicatechin, quercetin, caffeic acid, kaempferol and quinic acid. ${ }^{6}$

\section{Identification of phenol and flavonoid}

Identification of phenol and flavonoid were done/conducted using qualitative method of phytochemical screening and reagents spraying on Thin Layer Chromatography (TLC) plates.

For phenol identification, solution of iron trichloride 3\% was added to the sample solutions to see whether the color changed or not. For identification with spray reagents on the TLC plate, standard gallic acid was used as reference, dissolved in ethanol. Silica gel 60 F254 was used as the stationary phase and chloroform-acetone-formic acid (9:3:1) were used as the mobile phase. After the plate eluted, it was sprayed with solution of iron trichloride 3\%.

For flavonoid identification, zinc powder, magnesium powder and alumunium chloride spray reagent were used to see the color changes on sample solutions. For identification with spray reagents on the TLC plate, standard quercetin was used as reference, dissolved in ethanol. Silica gel 60 F254 was used as the stationary phase and chloroformacetone-formic acid (10:2:1) were used as the mobile phase. After the plate eluted, it was sprayed with alumunium chloride $5 \%$ and then viewed under $366 \mathrm{~nm}$ UV light.

\section{Determination of total phenolic content}

The determination of total phenol content was determined on microplate reader. ${ }^{10}$ Sample solutions were made in $5000 \mu \mathrm{g} / \mathrm{mL}$. Measurements started by preparing $20 \mu \mathrm{L}$ of sample solution mixed with $100 \mu \mathrm{L}$ of Folin-Ciocalteu reagent (1:4), shaken for a min in 96well microplate. The mixtures were left for two min. Then $75 \mu \mathrm{l}$ sodium carbonate solutions $(100 \mathrm{~g} / \mathrm{mL})$ were added and shaken for a min. After being left for $2 \mathrm{~h}$ at room temperature, the mixtures were measured using the microplate reader at $750 \mathrm{~nm}$ to get the absorbances. Blank solutions were measured without addition of samples or standard solution in well, which was replaced with methanol P. Gallic acid was used as standard, which were made in concentrations of $25,50,75,100$, 125 and $150 \mu \mathrm{g} / \mathrm{mL}$ to develop a calibration range.

\section{Determination of total flavonoid flavonoid content}

The determination of total flavonoid content was determined on spectrophotometer UV-Vis referred to Pharmacopoeia Herba Indonesia Suplement III. Sample solutions were made in $4000-10,000 \mu \mathrm{g} / \mathrm{mL}$. Measurements started by preparing $0.5 \mathrm{ml}$ sample solutions on the sample tubes. Then $1.5 \mathrm{~mL}$ of ethanol P, $0.1 \mathrm{~mL}$ of aluminum chloride $10 \%, 0.1 \mathrm{~mL}$ sodium acetate $(100 \mathrm{~g} / \mathrm{mL})$ and $2.8 \mathrm{ml}$ of distilled water were added to the sample tubes. The mixtures were shaken and left at room temperature for $30 \mathrm{~min}$. After that, the mixtures were measured using spectrophotometer UV-Vis at $415 \mathrm{~nm}$ to get the absorbances. Blank solutions were measured without addition of aluminum chloride $10 \%$, which was replaced with distilled water. Quercetin was used as standard, which were made in concentrations of 10, 20, 30, 40, 50 and $60 \mu \mathrm{g} / \mathrm{mL}$ to develop a calibration range.

\section{RESULTS AND DISCUSSION}

\section{Extraction}

Extraction is a separation process that separates the active compound from its matrix in plant using a selective solvent. Multistage UltrasoundAssisted Extraction (UAE) using n-hexane, ethyl acetate and methanol solvents were used based on the differences in polarity. The UAE method is used because this method is assisted by the use of ultrasound which can increase the permeability of the cell wall and form cavities to facilitate the release of bioactive compounds in simplicia. ${ }^{11}$ The polar methanol solvent showed the highest yield, followed by $n$-hexane which is non-polar and ethyl acetate which is semi-polar (Table 1).

\section{Arginase activity inhibition test}

Arginase activity inhibition test was determined using a microplate reader with a modified method of the Sigma Aldrich enzyme test protocol, which measured the production of urea-final product of the arginase reaction with L-arginine. Theoretically, the extract is considered to have a good enzyme inhibitory activity if it is able to inhibit enzyme activity more than or equal to $50 \%$ at concentration less than or equal to $100 \mu \mathrm{g} / \mathrm{mL}$. The results of extracts with $100 \mu \mathrm{g} / \mathrm{mL}$ final concentration showed that all three extracts had low potency of arginase inhibitory activity, which didn't reach $50 \%$ (Table 2).

\section{Identification of phenol and flavonoid}

Identification of phenol on n-hexane, ethyl acetate and methanol extract showed positive results using iron trichloride reagent, which would form a blackish green color after being added. The presence of phenol groups is characterized by the form of dark green or dark blue color due to the formation of complex compounds because of the addition of $\mathrm{Fe}^{3+}$. In addition, identification was also carried out using spray reagents on the TLC plates. The solution of gallic acid as standard and all three extracts were applied as spots on the TLC plate which was then eluted using the mobile phase of chloroform-acetone-formic acid (9:3:1). After the elution process was complete, the plate then sprayed with an iron trichloride. The results shown in the form of visible spots on the positive control of gallic acid and methanol extract with similar Rf.

Identification of flavonoid on n-hexane, ethyl acetate and methanol extract showed different results. The results shown was negative for $\mathrm{n}$-hexane extract and positive for ethyl acetate and methanol extract. It is the results classified as positive if orange or red color presence in the reaction using magnesium powder with hydrochloric acid and zinc powder with hydrochloric acid. The magnesium and zinc with the hydrochloric acid in the test would form a reaction that will reduce

Table 1: The percentage yield of plant extracts in different solvents.

\begin{tabular}{ccccc}
\hline No. & Solvent & $\begin{array}{c}\text { Simplicia's } \\
\text { Weight }(\mathbf{g})\end{array}$ & $\begin{array}{c}\text { Extract's } \\
\text { Weight }(\mathbf{g})\end{array}$ & Yield (\%) \\
\hline 1 & n-Hexane & 300.07 & 7.42 & 2.472 \\
2 & Ethyl acetate & 300.07 & 4.67 & 1.556 \\
3 & Methanol & 300.07 & 13.59 & 4.528 \\
\hline
\end{tabular}

Table 2: The percentage inhibition of Sangketan extracts.

\begin{tabular}{cccc}
\hline Sample & \% Inhibition & SD & CV (\%) \\
\hline n-Hexane extract & 9.5617 & 0.7355 & 7.6923 \\
Ethyl acetate extract & 17.5818 & 2.8440 & 12.4243 \\
Methanol extract & 29.7765 & 4.5250 & 15.1966 \\
\hline
\end{tabular}


the nucleus of benzopirone in the flavonoid structure which led to the color changes into orange or red. It can also be classified as positive when yellow fluorescent was seen when viewed under UV light at $366 \mathrm{~nm}$ after spraying alumunium chloride. In addition, quercetin as standard and three extracts on the TLC plate were also applied as spots and then eluted using the mobile phase of chloroform-acetoneformic acid (10:2:1). When the elution process was complete, the plate then sprayed with alumunium chloride. The results showed that there were fluorescent spots on the plates where the solution of quercetin, n-hexane extract, ethyl acetate extract and methanol extract with similar Rf viewed under UV light at $366 \mathrm{~nm}$.

The identification results can be associated with previously performed enzyme test results that phenolic and flavonoid compound may play a role in inhibiting the arginase, but it can't be denied that other compounds may also have a role in it as well (Table 3 ).

\section{Determination of total phenolic content}

The determination of the total phenol content was carried out using Folin-Ciocalteu reagent with a microplate reader. The principle of the reaction that occurs between Folin-Ciocalteu reagents and phenolic compounds in the sample is the oxidation reaction and colorimetric reduction. The phosphomolybdate-phosphotungstate compounds in Folin-Ciocalteu reagent will be reduced by hydroxyl groups in phenolic compounds to form a blue molybdenum-tungsten complex. ${ }^{12}$ The addition of $\mathrm{Na}_{2} \mathrm{CO}_{3}$ solution was aimed to produce an alkaline atmosphere. This alkaline atmosphere was needed because the colorimetric reduction reaction can only occur in an alkaline atmosphere. The high intensity of blue color that formed was equivalent to the amount of phenolic compounds in the sample. The more intense the blue color produced indicates that the higher the content of phenol compounds. The determination started by making the standard gallic acid calibration curve. The linear regression equation that resulted will be used to calculate the total phenol content of the sample. Measurements were made using a microplate reader at a wavelength of $750 \mathrm{~nm} .{ }^{13}$ The linear regression equation was $\mathrm{y}=0.0068 \mathrm{x}-0.0069(\mathrm{r}=$ 0.99985 ). The average total phenol content were obtained by inserting the absorbance of the extract into the linear regression equation. If the percentage value of enzyme inhibitory activity was associated, then the result of total phenolic content can also be said to have a correlation.
The lowest $n$-hexane extract with inhibition percentage also had the lowest amount of total phenol content, while methanol extract with the highest inhibition percent had the highest amount of total phenol content. It is known in several previous studies that several compounds which able to inhibit the activity of arginase enzymes are generally classified as flavonoids, where flavonoids are derivatives of the phenol group. Therefore, the high phenolic content in a sample can indicate the high content of flavonoids in the sample (Table 4). ${ }^{12}$

\section{Determination of total flavonoid content}

The determination of total flavonoid content was carried out using the colorimetric method using UV-Vis spectrophotometry with aluminum chloride and sodium acetate reagents. The calculation results are then stated in milligram quercetin equivalent/g sample. Quercetin was selected as a standard because it is classified as flavonoid in flavonol group which has keto group on C-4 atom and hydroxyl group in C-3 and C-5 atoms. The principle of this determination of total flavonoid content using alumunium chloride reagent is the formation of acidresistant complexes between aluminum ions with C-4 keto groups and C-3 or C-5 hydroxyl groups in flavonoids resulted in a form of yellow color. The addition of sodium acetate can detect the presence of free 7-hydroxyl groups in flavones and flavonols. This study began with making the standard quercetin calibration curve. The linear regression equation that resulted will be used to calculate the total flavonoid content of the sample. Measurements were made using UV-Vis spectrophotometry at $430 \mathrm{~nm}$, which wavelength shown the maximum absorption. The linear regression equation was $y=0.0076 x+0.1327(r=$ 0.99905). The average total flavonoid content were obtained by inserting the absorbance of the extract into the linear regression equation that previously obtained from the quercetin calibration curve. Similar to the results of total phenolic content, when the results of total flavonoid content were associated with the value of enzyme inhibitory activity, it showed a correlation. N-hexane extract with the lowest inhibition percent turned out to have the lowest amount of total flavonoid levels, while methanol extract with the highest inhibition percentage shown the highest amount of total flavonoid levels. It is known in several previous studies that some compounds which able to inhibit the activity of arginase enzymes are generally classified as flavonoids (Table 5).

Table 3: Identifiction of phenol and flavonoid in Sangketan extracts.

\begin{tabular}{cccc}
\hline Chemical Content & $\mathrm{n}$-Hexane extract & Ethyl acetate extract & Methanol extract \\
\hline Phenol & + & + & + \\
Flavonoid & - & + & + \\
\hline
\end{tabular}

Table 4: Total phenolic content of Sangketan extracts.

\begin{tabular}{ccc}
\hline Sample & Absorbance & Average Phenol Content (mgGAE/g sampel) \\
\hline & 0,345 & \\
n-Hexane Extract & 0,349 & 3,917 \\
& 0,337 & \\
& 0,482 & 4,830 \\
Ethyl Acetate Extract & 0,470 & \\
& 0,466 & 11,189 \\
Methanol Extract & 1,039 & \\
& 1,041 & \\
\hline
\end{tabular}


Rahmawati, et al.: Inhibitory Effects of Sangketan (Achyranthes aspera L.) Roots Extract on Arginase Activity and Determination of Its Total Phenolic and Flavonoid Contents

Table 5: Total flavonoid content of Sangketan extracts.

\begin{tabular}{ccc}
\hline Sample & Absorbance & Average Flavonoid Content (mgQE/g sampel) \\
\hline \multirow{3}{*}{ n-Hexane Extract } & 0,431 & 0,296 \\
& 0,437 & \\
& 0,438 & \multirow{2}{*}{0,804} \\
Ethyl Acetate Extract & 0,596 & \\
& 0,589 & 0,884 \\
Methanol Extract & 0,580 & \\
& 0,513 & \\
\hline
\end{tabular}

\section{CONCLUSION}

The roots extract of Sangketan had low potency of arginase inhibitory activity.

\section{ACKNOWLEDGEMENT}

This research was funded by Doctoral Grant 2018 from Universitas Indonesia.

\section{CONFLICTS OF INTEREST}

There is no conflicts of interest.

\section{ABBREVIATIONS}

eNOS: Endothelial nitric oxide synthase; NO: Nitric oxide; g: Gram; $\mu \mathrm{g}$ : Microgram; ml: Milliliter; $\boldsymbol{\mu l}$ : Microliter; mgGAE/gram: Milligram gallic acid equivalent per gram of sample; $\mathbf{m g Q E} / \mathbf{g r a m : ~ M i l l i g r a m ~}$ quercetin equivalent per gram of sample; UV-Vis: Ultraviolet-visible; MnSO$_{4}$ : Manganese sulfate; U: Unit; $\mathbf{m M}$ : Millimolar; h: Hour; min: Minute; C: Celcius; IC $_{50}$ : Inhibition concentration 50\%; \%: Percentage; TLC: thin layer chromatography; nm: Nanometer; UAE: Ultrasoundassisted extraction; SD: Standard deviation; CV: Coefficient of variation.

\section{REFERENCES}

1. Pandey NK, Sharma HP, Amit P, Paras J. A review on potential magic folk herbal medicinal plant: Achyranthes aspera L. International Journal of Medicinal Plants Photon. 2013;105:350-63.

2. Bhosale UA, Yegnanarayan R, Pophale P, Somani R. Effect of aqueous extracts of Achyranthes aspera Linn. on experimental animal model for inflammation. Anc Sci Life. 2012;31(4):202-6.
3. Gould A, Naidoo C, Candy GP. Arginine metabolism and wound healing. WHSA 2008;1(1):48-50

4. Steppan J, Nyhan D, Berkowitz DE. Development of novel arginase inhibitors for therapy of endothelial dysfunction. Front Immunol. 2013;4(SEP):1-6.

5. Kavalukas SL, Uzgare AR, Bivalacqua TJ, Barbul A. Arginase inhibition promotes wound healing in mice. Surgery. 2012;151(2):287-95

6. Bordage S, Pham TN, Zedet A, Gugglielmetti AS, Nappey M, Demougeot C, et al. Investigation of mammal arginase inhibitory properties of natural ubiquitous polyphenols by using an optimized colorimetric microplate assay. Planta Med. 2017;83(7):647-53

7. Cray JA, Bhaganna P, Singhal RS, Patil SV, Saha D, Chakraborty R, et al. Chaotropic and hydrophobic stress mechanism of antifungal substances. In Dehne HW, Deising HB, Fraaije B, Gisi U, Hermann D, Mehl A, et al. editors. Modern fungicides and antifungal compounds, vol VII. Braunschweig: Deutsche Phytomedizinische Gesellschaft. 2014;73-80.

8. Girard-Thernier C, Pham TN, Demougeot C. The promise of plant-derived substances as inhibitors of arginase. Mini Rev Med Chem. 2015;15(10):798808

9. Zalsabela TL, Elya B, Noviani A. Arginase inhibition activity of stem bark extract of Caesalpinia pulcherrima. J Young Pharm. 2018;10(2):111-3.

10. Bobo-garcía G, Davidov-pardo G, Arroqui C, Marín-arroyo MR. Intra-laboratory validation of microplate methods for total phenolic content and antioxidant activity on polyphenolic extracts and comparison with conventional spectrophotometric methods. J Sci Food Agric. 2014;95(1):204-9.

11. Medina-Torres N, Ayora-Talavera $T$, Espinosa-Andrews $H$, Sánchez-Contreras A, Pacheco N. Ultrasound assisted extraction for the recovery of phenolic compounds from vegetable sources. Agronomy. 2017;7(3):47.

12. Adawiah A, Sukandar D, Muawanah A. Antioxidant Activity and the content of bioactive components NAMNAM juice. Jurnal Kimia Valensi. 2015;1(2):130-6

13. Indonesian Herbal Pharmacopeia Ed I. 3th Supplement. Jakarta: Ministry of Health Republic of Indonesia. 2013

\section{SUMMARY}

The results of total phenolic and flavonoid content were associated with the value of enzyme inhibitory activity because it showed a correlation. It is known in several previous studies that some compounds which able to inhibit the activity of arginase enzymes are generally classified as flavonoids, where flavonoids are derivatives of the phenol group. But the extract of Sangketan roots still had low potency of arginase inhibitory activity, consecutively from the lowest potential were $n$-hexane extract $(9.56 \%)$, ethyl acetate extract (17.58\%) and methanol extract (29.77\%) with $100 \mu \mathrm{g} / \mathrm{mL}$ final concentration. Phenolic and flavonoid compounds may play a role in inhibiting the arginase, but it can't be denied that other compounds may also have a role in it as well.

Cite this article: Rahmawati DS, Elya B, Noviani A. Inhibitory Effects of Sangketan (Achyranthes aspera L.) Roots Extract on Arginase Activity and Determination of Its Total Phenolic and Flavonoid Contents. Pharmacog J. 2019;11(6):1231-4. 